\title{
Pengaturan Pengelolaan Dan Pengawasan Keuangan Negara Terhadap Badan Usaha Milik Negara (BUMN)
}

\author{
Akbar Baitullah ${ }^{1}$ \\ Universitas Trunojoyo Madura \\ akbarbaitullah01@gmail.com \\ Dr. Indah Cahyani \\ Universitas Trunojoyo Madura
}

\begin{abstract}
ABSTRAK
Badan Usaha Milik Negara atau BUMN merupakan salah satu badan usaha berbentuk perusahaan yang dimiliki oleh negara yang seluruh atau sebagian besar modalnya dimiliki oleh negara melalui penyertaan secara langsung yang berasal dari kekayaan negara yang dipisahkan. Problematika yaitu adanya konflik hukum atau disharmonisasi antar peraturan perundang-undangan terkait pola pengawasan pada BUMN tersebut, utamanya pada pengelolaan keuangan. Metode penelitian yang digunakan adalah normatif, penelitian ini dilakukan dengan tujuan untuk memberikan argumentasi hukum. Adapun pendekatan penelitian yang digunakan adalah pendekatan perundang-undangan (Statute Approach) dan Pendekatan Kasus (Case Approach). Penelitian ini menghasilkan Pertama, berdasarkan konflik hukum yang ada sangat penting untuk membuat aturan terkait penyertaan modal negara yang sudah dilaksanakan terhadap BUMN. Kedua, ketidakpastian hukum karena perbedaan istilah BUMN antara Undang-Undang Keuangan Negara dengan Undang-Undang BUMN perlu ditegaskan kembali terkait BUMN sebenarnya berstatus negeri atau swasta.
\end{abstract}

\section{Kata kunci: Pengelolaan Keuangan Negara, Pengawasan BUMN}

\section{ABSTRACT}

State Owned Enterprises or BUMN are business entities in the form of companies owned by the state whose entire or most of the capital is owned by the state through direct investment originating from separated state assets. The problem is that there is a legal conflict or disharmony between laws and regulations related to the supervision pattern in the BUMN, especially in financial management. The research method used is normative, this research was conducted with the aim of providing legal arguments. The research approach used is the statutory approach and the case approach. This research results first, based on the existing legal conflicts, it is very important to make rules related to the participation of state capital that have been implemented for SOEs. Second, legal uncertainty due to the difference in the term BUMN between the State Finance Law and the BUMN Law needs to be reaffirmed regarding BUMN actually having a public or private status.

Keywords: State Financial Management, BUMN Suprvision 


\section{PENDAHULUAN}

Badan Usaha Milik Negara atau BUMN yaitu salah satu badan usaha yang dapat berbentuk perusahaan yang dapat dimiliki oleh negara. BUMN adalah "badan usaha yang seluruh atau sebagian besar modalnya dimiliki oleh negara rnelalui penyertaan secara langsung yang berasal dari kekayaan negara yang dipisahkan”. Payung hukum dari keberadaan BUMN ini yaitu diatur dalam "Undang-Undang Nomor 19 Tahun 2003 tentang BUMN" (selanjutnya disebut Undang-Undang BUMN). Di dalam aturan "Peraturan Pemerintah Nomor 45 Tahun 2005 Tentang Pendirian, Pengurusan, Pengawasan, dan Pembubaran BUMN Pasal (4) dan (5) menjelaskan bahwasanya Pendirian BUMN ditetapkan dengan peraturan pemerintah dan pendiriannya meliputi pembentukan perum atau persero baru, perubahan bentuk unit instansi pemerintah menjadi BUMN, perubahan bentuk badan hukum BUMN, dan pembentukan BUMN sebagai akibat dari peleburan persero dan perum”. Sehingga di dalamhal pendirian BUMN ini dapat dilakukan dengan mengalihkan unit instansi pemerintah yang dapat menjadi BUMN, maka di dalam suatu peraturan pemerintah ini yang dapat memuat ketentuan bahwa seluruh atau sebagian yang dilakukan dalam suatu kekayaan, hak dan kewajiban unit instansi pemerintah tersebut ini nantinya dapat beralih menjadi kekayaan, hak dan dapat beralih menjadi kewajiban BUMN yang dapat didirikan.

Problematika utama dalam pengelolaan BUMN yaitu berkaitan dengan peraturan perundang-undangan yang mengatur terkait BUMN itu sendiri. Problematika tersebut yaitu adanya disharmonisasi antar peraturan perundangundangan terkait pola pengawasan pada BUMN tersebut, utamanya pada pengelolaan keuangan. Namun, permasalahan tumpang tindihnya peraturan perundang-undangan tersebut, tidak dapat dilakukan upaya uji materi (judicial review) ke Mahkamah Konstitusi, hal tersebut dikarenakan Mahkamah Konstitusi ini dapat menyatakan bahwasannya undang-undang tidak dapat dilakukan dengan diuji dengan undangundang lainnya karena hal ini posisinya adalah setara atau sama. Akan tetapi, di dalam undang-undang yang dapat dijadikan dasar pengujian tersebut bisa berbalik menjadi obyek terhadap suatu pengujian. 1

Dengan demikian, penugasan pemerintah tersebut harus dapat melakukan dengan disertai adanya suatu pembiayaannya (kompensasi) berdasarkan suatu prinsip atau yang dilakukan dalams uatu perhitungan bisnis atau komersial, sedangkan untuk Perum ini maka yang dilakukan dalam tujuannya menyediakan barang dan jasa tersebut untuk kepentingan umum, sehingga di dalam suatu pelaksanaannya harus dapat memperhatikan prinsip-prinsip yang dilakukan dalam suatu pengelolaan perusahaan yang sehat. Kemudian pada Pasal 4 ayat (1) menyatakan "Modal BUMN merupakan dan berasal dari kekayaan negara yang dipisahkan". Pasal tersebut mendefinisikan frasa "dipisahkan" yaitu "pemisahan kekayaan dari Anggaran Pendapatan dan Belanja Negara atau APBN

1 Yudho Taruno Muryanto, Tata Kelola BUMD (Konsep, Kebijakan, Dan Penerapan Good Corporate Governance), Malang, Instrans Publishing, 2017,hlm. 78. 
untuk dijadikan penyertaan modal negara pada BUMN yang mana pembinaan dan pengelolaannya tidak lagi didasarkan pada sistem APBN, melainkan didasarkan pada prinsip-prinsip perusahaan yang sehat". Hal tersebut mengartikan bahwasannya BUMN digambarkan sebagai badan usaha yang dikelola secara swasta, dan bukan secara negeri. Karena apabila BUMN dikelola dengan berpedoman pada prinsip-prinsip perusahaan yang sehat, maka artinya secara hukum privat berlaku pula ketentuan pada Undang-Undang Nomor 40 Tahun 2007 tentang Perseroan Terbatas (selanjutnya disebut Undang-Undang PT).

Disisi lain, "Undang-Undang Nomor 17 Tahun 2003 tentang Keuangan Negara (selanjutnya disebut Undang-Undang Keuangan Negara)" sebagai pengatur serta payung hukum dari konsep kekayaan negara, yang menjelaskan pengertian dari keuangan negaratersebut yang berdasarkan "Pasal 1 angka 1 yang menyatakan merupakan semua hak dan kewajiban negara yang dapat dinilai dengan uang, serta segala sesuatu baik yang berupa uang maupun berupa barang yang dapat dijadikan milik negara berhubung dengan pelaksanaan hak dan kewajiban tersebut". Kemudian pada Pasal 2 dijabarkan apa yang menjadi kriteria dari keuangan negara tersebut, yaitu pada huruf g yang menyatakan "kekayaan negara atau kekayaan daerah yang dikelola sendiri atau oleh pihak lain berupa uang, surat berharga, piutang, barang, serta hak-hak lain yang dapat dinilai dengan uang,termasuk kekayaan yang dipisahkan pada perusahaan negaral perusahaan daerah”. Lalu pada Pasal 2 huruf i yang menyatakan "kekayaan pihak lain yang diperoleh dengan menggunakan fasilitas yang diberikan pemerintah”. Undang-Undang Keuangan Negara pada Pasal 11 menegaskan bahwa APBN merupakan wujud dari pengelolaan keuangan negara. Sehingga artinya, didalam Undang-Undang Keuangan Negara mengakui bahwa Perusahaan Negara adalah milik Negara, bukan swasta.

Demikianlah, Undang-Undang Keuangan Negara mengakui bahwa BUMN merupakan badan usaha yang berstatus milik Negara. Sedangkan, pada "Undang-Undang BUMN mengakui bahwa Perusahaan BUMN adalah badan usaha yang berstatus swasta, karena sebagai badan hukum privat artinya tunduk pada Undang-Undang PT". Sehingga dengan hal tersebut menimbulkan adanya perbedaan pemahaman dan terjadilah tumpang tindih peraturan perundangundangan yang mana hal tersebut dapat berdampak pada adanya ketidakpastian hukum bagi para pihak yang terlibat dalam pengelolaan keuangan negara. Dampak yang signifikan adalah apabila suatu BUMN dikelola secara negeri dan jika terjadi kerugian pada badan usaha tersebut, maka hal tersebut bisa menimbulkan suatu peristiwa pidana yang dalam hal ini adalah tindak pidana korupsi. Sedangkan, apabila suatu BUMN dikelola dengan berpedoman kepada suatu prinsip-prinsip yang dilakukan dalam tata kelola perusahaan yang sehat, maka hal ini akan tunduk pada Undang-Undang PT.

Menurut Prinsip Pertanggungjawaban dan Kemampuan Pengurus (Fiduciary Duties), apabila dalam melaksanakan tugasnya yaitu "pengurus perseroan dapat terbukti telah melanggar dalam salah satu atau beberapa rambu seperti 
memiliki adanya suatu iktikad buruk terhadap perseroan, atau ternyata dalam kemampuannya (skill) rendah/tidak memadai dan/atau sembrono/kurang hati-hati yang dilakukan dalam menjalankan tugas, yang mana hal tersebut dilakukan dalam kesemuanya itu dan dapat mengakibatkan perseroan mengalami kerugian, maka terhadap anggota pengurus yang bersangkutan dapat dituntut untuk bertanggungjawab penuh, termasuk dengan harta pribadinya, untuk menutupi kerugian yang dialami perseroan".2

Berdasarkan uraian yang dijelaskan, maka penulis tertarik untuk membahas mengenai:

1. Bagaimanakah pengaturan pengelolaan keuangan negara pada Badan Usaha Milik Negara (BUMN) ?

2. Bagaimanakah pengaturan pengawasan keuangan negara pada Badan Usaha Milik Negara (BUMN) ?

Berdasarkan rumusan masalah di atas, maka tujuan agar supaya tercapainya dari penelitian ini adalah sebagai berikut:

1. Untuk menganalisis pengaturan pengelolaan keuangan negara pada BUMN.

2. Untuk menganalisis pengaturan pengawasan keuangan negara pada BUMN.

\section{METODE PENELITIAN}

Metode penelitian digunakan untuk menganalisis suatu fenomena permasalahan hukum. Analisis dilakukan terhadap fakta

2 Muchyar Yara, "Prinsip-Prinsip Sistem Perseroan Terbatas Menurut Undang-Undang Nomor 1 Tahun 1995", Jurnal Hukum dan Pembangunan, Nomor 3, Juni 1995, hlm. 240. yang terjadi dalam permasalahan hukum. Langkah berikutnya yakni dilakukan pemecahan masalah dari permasalahan hukum tersebut. Penelitian ini termasuk dalam jenis penelitian hukum normatif. Penelitian ini menitik beratkan pada konsep-konsep yang kemudian dapat dikembangkan atas dasar dalam suatu doktrin-doktrin yang dapat dianut dan menggunakan studi dalam kepustakaan Penelitian ini yang mana lebih mengutamakan pada penggunaan data secara sekunder, serta data primer hanya sebagai data yang dilakukan secara pendukung dari data sekundernya. Pendekatan penelitian "ini menggunakan pendekatan perundangundangan (statue approach) yakni dilakukan dengan menelaah suatu peraturan perundangundangan yang mana dapat berhubungan dengan Badan Usaha Milik Negara (BUMN). Pendekatan kasus (case approach), yakni suatu putusan yang dilakukan oleh suatu pengadilan yang mana telah mempunyai kekuatan hukum tetap. Pendekatan kasus ini menggunakan "Putusan Mahkamah Konstitusi Nomor 62/PUU-XI/2013" yang akan ditelaah untuk DAPAT menjadi referensi terhadap suatu isu hukum yang sedang diteliti saat ini yaitu pengaturan pengelolaan dan pengawasan BUMN. Yang menjadi kajian pokok dalam pendekatan kasus ini adalah ratio decidendi atau reasoning yaitu pertimbangan Majelis Hakim untuk sampai kepada suatu putusan yang in kracht.

\section{Analisisa Bahan Hukum}

Berdasarkan penelitian ini dapat dilakukan identifikasi terkait dengan suatu fakta-fakta hukum yang mengenai hal-hal yang dilakukan secara tidak relevan di dalam menetapkan dalam isu hukum yang sedang 
diteliti, Mengumpulkan semua bahan-bahan hukum yang mempunyai kaitan dengan isu hukum yang sedang diteliti, mengumpulkan bahan-bahan yang non hukum, Menalaah permasalahan yang dikumpulkan lalu dibahas dan diajukan dalam penelitian, dan dapat Memberikan preskripsi berdasarkan argumentasi yang telah ada didalam kesimpulan.

\section{PEMBAHASAN}

1. Analisis Pengaturan Pengelolaan Keuangan Negara Pada Badan Usaha Milik Negara (BUMN)

Pengelolaan Keuangan Negara ini dapat dilakukan dengan di kelola oleh pejabat pengelola keuangan negara yang mana dapat sesuai dengan adanya suatu kedudukan dan juga adanya suatu kewenangannya, yang dapat meliputi terhadap suatu perencanaan,pelaksanaan,pengawas,

danpertanggungjawaban. "Anggaran pendapatan dan belanja negara sebagai wujud dari pengelolaan keuangan negara ditetapkan setiap tahun dengan undangundang pengertian/ruang lingkup keuangan negara dan kekayaan negara dalam ketentuan Pasal 2 huruf $g$ dan huruf $i$ UU Keuangan Negara bertentangan dengan Pasal 23 ayat (1) UU Keuangan Negara”.

Terhadap ketentuan yang dilakukan dalam "Pasal 23 ayat (1) UUD 1945 menyatakan bahwa Anggaran Pendapat dan Belanja Negara sebagai wujud dari pengelolaan keuangan negara ditetapkan setiap tahun dengan undang-undang dan dilaksanakan secara terbuka dan bertanggung jawab sebesar- besarnya kemakmuranrakyat". Terhadap ketentuan yang terdapat di dalam "Pasal 23 E ayat (1) UUD 1945 mengatur lebih lanjut kewenangan Badan Pemeriksa Keuangan dalam memeriksa Keuangan Negara: Untuk memeriksa pengelolaan dan tanggung jawab keuangan negara diadakan suatu Badan Pemeriksa Keuangan yang bebas danmandiri”. Dari bunyi ketentuan dasar sebagaimana yang diatur dalam UUD 1945 di atas, yaitu "berarti ruang lingkup, tugas, dan fungsi pemeriksaan yang dapat dilakukan oleh BPK bersifat terbatas atau limitatif pada pengelolaan keuangan negara yang terwujud dalam bentuk Anggaran Pendapatan dan Belanja Negara.

Terhadap ketentuan yang terdapat di dalam "Pasal 4 ayat (1) UU BUMN dalam Penjelasannya menyatakan bahwa Yang dimaksudkan dengan dipisahkan adalah pemisahan kekayaan negara dari Anggaran Pendapat dan Belanja Negara untuk dijadikan modal negara pada BUMN untuk selanjutnya pembinaan dan pengelolaannya tidak lagi didasarkan pada sistem Anggaran Pendapatan dan Belanja Negara, namun pembinaan dan pengelolaannya didasarkan pada prinsip-prinsip perusahaan yangsehat". Namun demikian, yaitu "cakupan ruang lingkup kewenangan yang diatur dalam UU BPK - yang semestinya hanya terbatas pengelolaan keuangan negara yang terwujud dalam Anggaran Pendapatan dan Belanja Negara sebagai mana diamanatkan dalam Pasal 23ayat (1) dan Pasal 23E ayat (1) UUD 1945 - ternyata juga menjangkau BUMN yang telah nyata-nyata dipisahkan dari sistem Anggaran Pendapatan dan Belanja Negara". Hal ini dilakukan 
seperti nyata dalam pengaturan berikut:

Pasal 6 ayat (1) UU BPK: “BPK bertugas memeriksa pengelolaan dan tanggung jawab keuangan negara yang dilakukan oleh Pemerintah Pusat, Pemerintah Daerah, Lembaga Negara lainnya, Bank Indonesia, Badan Usaha Milik Negara, Badan Layanan Umum, Badan Usaha Milik Daerah, dan lembaga atau badan lain yang mengelola keuanganNegara".

Pasal 10 ayat (1) UU BPK: "BPK menilai dan/atau menetapkan jumlah kerugian negara yang diakibatkan oleh perbuatan melawan hukum baik sengaja maupun lalai yang dilakukan oleh bendahara, pengelola BUMN/BUMD, dan lembaga atau badan lain yang menyelenggarakan pengelolaan keuangan negara".

Bahwa yang dilakukan terhadap suatu inkonsistensi yang mana dapat terhadap suatu akibat yang timbul akibat adanya ketentuan UU BPK di atas khususnya yang berkaitan dengan pemeriksaan, pertanggungjawaban, dan juga dapat dilakukan dengan distribusi risiko dalam suatu pengelolaan keuangan BUMN, hal ini tentunya tidak dilakukan dengan tidak diragukan lagi yang dapat menimbulkan adanya suatu irasionalitas yang dilakukan di dalam pengaturan keuangan negara yang merupakan "bagian dari keuangan publik, di mana dalam praktiknya akan merugikan kedudukan hukum BUMN selaku badan hukum privat karena tidak adanya perbedaan secara tegas mana badan hukum publik dan badan hukum perdata yang menjadi bagian ruang lingkup kewenangan Badan Pemeriksa Keuangan selaku pemeriksa pengelolaan keuangan negara". Seharusnya, setelah dilakukan terhadap putusan MK tersebut di atas, maka hal ini dapat dilakukan suatu pengelolaan piutang yang macet yang man nantinya akan dilakukan terhadap suatu pada bank BUMN hal ini yaitu "memiliki dasar hukum yang kuat untuk dikelola berdasarkan Undang-Undang Perbankan, Undang-Undang PT, dan peraturan lainnya sebagaimana dilakukan oleh bank-bank swasta nasional di Indonesia, atau dengan kata lain bank BUMN kini memiliki landasan hukum untuk mendapatkan level of playing field yang sama dengan bank-bank swasta nasional diIndonesia; Namun demikian, dalam praktiknya putusan”.Terhadap suatu Mahkamah Konstitusi belum berlaku yang dilakukan secara efektif karena masih terkendala dengan adanya suatu penafsiran yang dilakukan dengan berbeda dari para pemangku terhadap suatu kepentingan.

Sehubungan dengan ketentuan dalam "Pasal 2 huruf g Undang-Undang Nomor 17 Tahun 2003 tentang Keuangan Negara yang menyatakan bahwa lingkup keuangan negara termasuk kekayaan yang dipisahkan pada perusahaan negara/perusahaan daerah, sehingga sampai saat ini, putusan MK tersebut tidak bisa dilaksanakan dalam praktik. Hal tersebut sangat menodai sistem ketetanegaraan yang dibangun oleh UndangUndang Dasar 1945 dan dijaga oleh Mahkamah Konstitusi yang sangat muliaini; Mengingat kapasitas saya dalam hal ini selaku direktur utama PT Bank Negara Indonesia Persero Tbk"., dan sebagai Ketua Himbara, maka yang perlu saya sampaikan terhadap hal-hal yang dilakukan secara spesifik terkait dengan adanya suatu BUMN yang mana dapat 
bergerak disektor perbankan sebagai berikut. Pertama yaitu "BUMN khususnya perbankan selain tunduk pada Undang-Undang BUMN dan Undang- Undang PT juga wajib memenuhi semua ketentuan yang diatur dalam Undang-Undang Perbankan dan Undang-Undang Pasar Modal sehingga pengelolaan bersifat transparan dalam bentuk laporan keuanganyang terpublikasikan. Kedua, Bank BUMN selain diawasi atau diaudit oleh Bank Indonesia atau Otoritas Jasa Keuangan juga diaudit oleh akuntan publik. Ketiga, peran negara dalam mengontrol bank BUMN tetap dalam dilaksanakan oleh eksekutif yang ditunjuk oleh pemerintah atas dasar kepemilikan saham Dwi Warna dalam batasan sebagai pemegang saham sebagaimana layaknya pemegang saham", sehingga yang dilakukan tersebut pada perusahaan swasta yang mana hal ini dapat dilakukan dengan tunduk pada undangundang tentang perseroan terbatas. ${ }^{3}$

\section{Analisis Pengaturan Pengawasan Keuangan Negara Pada Badan usaha Milik Negara (BUMN)}

Setiap badan hukum yang berbentuk perusahaan dipastikan terdapat alat perlengkapan yaitu pengawasan. Pengawasan dilaksanakan sebagai kontrol pekerjaan seorang direksi yang mempunyai tugas mengurus perusahaannya. Seperti kita ketahui bahwa seluruh kegiatan perusahaan di pegang oleh seorang direksi. Dengan pengawasan tersebut agar didalam pengawasannya berlandaskan pada anggaran yang dilakukan pada dasar dan peraturan perundang-

3 Putusan MK Nomor 62/PUU-XI/2013 undangan yang dilakukan sedang berlaku. Untuk dapat melaksanakan pengawasan yang baik dan lancar maka pengawasnya haruslah orang yang mempunyai pengetahun yang memadai tentang tata kelola perusahaan dan mempunyai pengalaman yang cukup. Di samping itu sebaiknya ditunjang dengan latar belakang pendidikan yang sejalan usha perusahaan.

Pada umumnya pemeriksaan dilakukan secara rutin atau berkala dengan cara memeriksa secara administrasi dengan melihat surat dan memeriksa kepada orang dengan cara berdialog atau wawancara. Hsil pemeriksaan tersebut dapat dituangkan kedalam bentuk catatan atau berita yang berbentuk dokumen perusahaan dan dilakukan penyimpanan. Kelancaran di dalam menjalankan perusahaan salah satunya dipengaruhi oleh kualitas kerja sama antara direksi dengan pengawas, dimana direksi bersikap terbuka ketika diawasi oleh pengawas, sedangkan pengawas di dalam bertindak dengan penuh kejujuran dan berdasarkan standar pengawasan serta menjauhi kesewenangannya. Selain itu BUMN kerja sama antara pengawas dengan pengurus ditunjukkan ketika membuat laporan tahunan yang ditandatangani secara bersamasama oleh mereka.

Dalam implementasi doktrin BJR di Indonesia, meskipun yang dilakukan terhadap suatu kebijakan yang diambil oleh direksi yaitu "masuk kedalam ranah BJR, namun penegak hukum cenderung mengabaikan hal tersebut, seperti pada kasus yang terjadi pada Hotasi Nababan selaku Direktur Utama PT. Merpati Nusantara Airlines. Hotasi Nababan 
membayar security deposit sebesar \$1 Juta US dollar sebagai jaminan pembelian 2 pesawat boeing 737-400 dan boeing 737-500 kepada pihak lessor, Thirdstone Air craft Leasing Group (TALG)". Perbuatan Hotasi Nababan ini sendiri telah dilakukan dan juga dapat disetujui oleh jajaran direksi dan dilakukan dalam pengambilan putusannya telah dilakukan dengan alasan dan juga dapat didasarkan dengan perhitungan business. Namun pada akhirnya, ini pada TALG gagal untuk dapat menyerahkan kedua pesawat serta dapat menolak dan dapat mengembalikan deposit tersebut.

PT MNA tersebut telah menyetujui adanya suatu proposal yang diajukan TALG, yang mana dapat dituangkan di dalam 2 Lease Agreement Summary of Terms (LASOT), yang merupakan dokumen lazim yang terdapat di dalam penyewaan pesawat, masing-masing ini dilakukan untuk pesawat Boeing 737 seri 400 dan 500, yang mana dapat ditandatangani oleh Tony Sudjiarto yang mana dapat mewakili PT MNA dan Alan Messner selaku CEO TALG. Adapun isi yang terdapat kesepakatan dalam LASOT tersebut antara lain yaitu:

1. "Kewajiban yang dilakukan oleh PT MNA yaitu menempatkan dalam security deposit di Kantor Hukum Hume \& Associates PC sejumlah US\$ 500,000 untuk 1 (satu) pesawat sebagai jaminan penyewaan pesawat;

2. PT MNA harus membayar security deposit yaitusatu hari setelah TALG menandatangani purchase

agrrement dengan East Dover Ltd. Atau pemilik terakhir;
3. TALG yaitu dilakukan wajib mengembalikan security deposit jika gagal menyerahkan pesawat”.

Pembayaran yang dilakukan dalam menggunakan mekanisme security deposit yang ditempatkan di pihak ketiga, yaitu "Hume \& Associates, dilakukan karena pihak TALG hanya mau menerima pembayaran dengan sistem tersebut. Mengingat buruknya tingkat kepercayaan PT MNA sedangkan PT MNA membutuhkan pesawat tersebut dalam waktu cepat guna menaikkan pedapatan mereka, maka PT MNA menyapakati cara pembayaran tersebut, yang mana cara pembayaran ini juga telah disetujui oleh semua anggota direksi PT MNA dengan menandatangani circularboard". Lagi pula, ini dilakukan dengan cara pembayaran tersebut juga sudah biasa yang mana dilakukan oleh PT MNA dan tidak ada masalah, dalam arti, apabila ini dilakukan dalam perjanjian batal, maka yang dilakukan ini terhadap uang tersebut akan dikembalikan kepada PT MNA. Sebelum melakukan pembayaran, ini yaitu "PT MNA berupaya untuk memastikan keamanan security deposit dengan menugaskan Laurence Siburian, yang adalah seorang advokat dari Indonesia yang sedang menempuh pendidikan doktorat di Amerika Serikat, untuk mengecek keberadaan TALG dan Kantor Hukum Hume \& Associates beserta segala hal terkait 2 (dua) kantor tersebut". dikarenakan ini terhadap waktu pengecekan yang singkat, Laurence tidak dilakukan dalam sempat memeriksa secara keseluruhan mengenai TALG dan Hume \& Associates, namun "untuk mendapatkan fakta bahwa kedua lembaga tersebut benar ada dan kantornya berada di 
satu gedung yang sama yang terletak tidak jauh dari Gedung Putih Amerika Serikat, yang adalah termasuk kawasan bonafit di Amerika". Informasi lain yang didapatkan adalah mengenai track record Alan Messner dan Jon Cooper selaku pimpinan TALG ini dalam penyewaan pesawat.

Selanjutnya, TALG yaitu "perjanjian yang mengikat terhadap jual beli pesawat dengan East Dover Ltd denganmenandatanganiSummary of Term for Sales (SOT) untuk dua pesawat Boeing 737 seri 400 dan 500. Kemudian, atas perjanjian tersebut, PT MNA melakukan pembayaran sesuai dnegan yang telah disepakati yaitu melalui mekanisme security deposit kepada TALG melalui Hume \& Associates senilai US\$ 1,000,000”. Namun, sampai waktu yang telah disepakati, TALG ini tidak juga mengirimkan pesawat yang dapat disewa oleh PT MNA. TALG meminta penambahan pembayaran dikarenakan adanya suatu berkembangnya keadaan bisnis. PT MNA yaitu "menyanggupinya dan membatalkan perjnajian tersebut serta meminta uang yang ada di security deposit untuk dikembalikan seluruhnya. Namun, kemudian, diketahui bahwa uang tersebut telah dicairkan dan digunakan untuk kepentingan pribadi Alan Messner dan John Cooper, dimana Alan Messner mendapatkan US\$ 810,000 dan John Cooper mendapatkan US\$ 190,000". Atas hal ini, PT MNA dengan bantuan JAMDATUN (Jaksa Agung Muda Bidang Perdata dan Tata Usaha Negara), yang dapat diwakili Yosep Suari Sabda selaku pengacara Negara, mengajukan terhadap suatu gugatan secara perdata di pengadilan "US District Court for the District of Columbia" terhadap Alan
Messner dan John Cooper, dimana dari suatu PT MNA memenangkan gugatan tersebut dan Alan Messner serta John Cooper ini dilakukan pada dihukum telah melakukan "wanprestasi" dan diperintahkan dan dilakukan dalam mengembalikan uang PT MNA beserta bunganya.

Pada akhirnya, hal tersebut dinilai oleh jaksa penuntut umum sebagai "pelanggaran hukum dan perbuatannya menimbulkan kerugian negara.Meskipun sesungguhnya Pengadilan Distrik Columbia (Amerika Serikat) telah mengadili pelaku penggelapan dana dan penipuan yang terjadi oleh Jon Cooper dan Alan Messner yang dilakukan terhadap uang deposit PT. Merpati Nusantara Airlines kepada TALG. Prof. Hikmahanto Juwana menyatakan, bahwa Hotasi Nababan tidak menimbulkan kerugian negara, kepentingan dirinya maupun orang lain atau korporasi”. Meskipun pada pengadilan pada tingkat pertama, Hotasi Nababan ini dapat hal ini dinyatakan tidak bersalah dikarenakan ini tidak memiliki mens rea, namun pada akhirnya, Hotasi Nababan ini dapat dilakukan dengan tetap divonis dengan 4 tahun penjara dan denda 200 juta subsider 6 bulan kurungan sebagaimana dalam Putusan MA Nomot 417 K/Pid.Sus/2014. Putusan yang dapat dijatuhkan kepada Hotasi Nababan tersebut mengabaikan doktrin BJR, karena "keputusan dan kebijakan yang diambil oleh Hotasi Nababan beserta jajaran direksi telah memperhatikan syarat syarat seperti good faith, due care and fiduciary duty.Mahkamah Agung (MA) tetap menghukum Hotasi Nababan selama 4 tahun penjara". Mantan Direktur Utama (Dirut) Merpati Nusantara Airlines (MNA) itu ini dapat dilakukan 
dengan adanya suatu terbukti melakukan tindak pidana korupsi yang merugikan negara USD 1 juta, sehingga di dalam kasus tersebut dapat dikategorikan sebagai suatu kasus tindak pidana korupsi. 4

\section{SIMPULAN}

Disharmonisasi antar peraturan perundang-undangan terkait pola pengawasan pada BUMN tersebut, utamanya pada pengelolaan keuangan mengakibatkan konflik hukum antar Undang-Undang. Selain itu, BUMN secara hukum bukanlah merupakan bagian dari kekayaan negara, berakibat terhadap status modal BUMN yang asalnya dari APBN bukan lagi bagian dari kekayaan negara, kemudian penyertaan modal negara yang sudah dilaksanakan terhadap BUMN hingga kini tidak mempunyai landasan hukum.

Konflik hukum pada pengaturan pengawasan keuangan negara pada BUMN sebagian besar modal BUMN yang berasal dari APBN dengan mekanisme penyertaan modal negara membawa konsekuensi bahwa BUMN merupakan bagian dari kekayaan negara, namun apabila secara hukum dinyatakan bahwa BUMN bukan sebagai bagian dari kekayaan negara, berdampak pada status modal BUMN yang berasal dari APBN bukan lagi merupakan bagian dari kekayaan negara.

4 Bayu Aji, Yogi. 2014. “Hotasi Berharap PK Dikabulkan Hakim untuk Kembalikan Uang Negara". 


\section{DAFTAR PUSTAKA}

Buku-Buku:

Encik Muhammad Fauzan, HukumTata Negara Indonesia, Malang, Setara Press, 2016.

Utang Rasyidin dan Dedi Supriyadi, Pengantar Hukum Indonesia: dari Tradisi ke Konstitusi, Bandung, Pustaka Setia, 2014.

M. Kadarisman, Manajemen Pengembangan Sumber Daya Manusia, Jakarta, Raja Grafindo Persada, 2012.

Maringan Masry Simbolon, Dasar-Dasar Administrasi dan Manajemen, Jakarta, Ghalia Indonesia, 2004.

Peter Mahmud Marzuki, Penelitian Hukum, Jakarta,PT Kharisma Putra Utama, 2016.

E. Utrech, Pengantar Dalam Hukum Indonesia, Jakarta, PT Ichtiar Baru, 1965.

Gatot Suparmono, BUMN ditinjau dari segi hukum perdata, Jakarta, PT Rineka Cipta 2016.

Sudikno Mertokusumo, Mengenal Hukum: Suatu Pengantar, Yogyakarta, Liberty, 1988.

Subekti, Pokok-Pokok Hukum Perdata, Jakarta, Intermasa, 2005.

C.S.T Kansil, Pengantar Ilmu Hukum, Jakarta, Balai Pustaka, 2002.

C.S.T Kansil, Pokok-Pokok Badan Hukum, Jakarta, Sinar Harapan, 2002.

Tri Rama K, Kamus Lengkap Bahasa Indonesia, Surabaya, Karya Agung,

Yohanes Yahya, Pengantar Manajemen, Yogyakarta, Graha Ilmu, 2006.
Sahya Anggara, Administrasi Keuangan Negara, Bandung, Pustaka Setia, 2016.

\section{PERATURAN PERUNDANG-}

UNDANGAN:

Undang-Undang Dasar Negara Republik Indonesia Tahun 1945.

Undang-Undang Nomor 17 Tahun 2003 Tentang Keuangan Negara.

Undang- Undang Nomor 19 Tahun 2003 Tentang Badan Usaha Milik Negara.

Undang- Undang Nomor 1 Tahun 2004 Tentang Perbendaharaan Negara.

Undang-Undang Nomor 15 Tahun 2006 Tentang Badan Pemeriksa Keuangan.

Undang-Undang Nomor 40 Tahun 2007 Tentang Perseroan Terbatas

Peraturan Pemerintah Nomor 45 Tahun 2005 Tentang Pendirian, Pengurusan, Pengawasan, dan Pembubaran BUMN.

JURNAL:

Muchyar Yara, "Prinsip-Prinsip Sistem Perseroan Terbatas Menurut Undang-Undang Nomor 1 Tahun 1995”, Jurnal Hukum dan Pembangunan, Nomor 3, Juni 1995.

Yudho Taruno Muryanto, Tata Kelola BUMD (Konsep, Kebijakan, Dan Penerapan Good Corporate Governance), Malang, Instrans Publishing, 2017.

Sang Made Satya Dita Permana, I Wayan Wiryawan, I Ketut Westra, 2016, "Kedudukan Hukum Direksi Terhadap Pengelolaan Perseroan Terbatas yang Belum Berstatus Badan Hukum", Jurnal Kertha Semaya, Vol. 04, No.03 April 2019.

Erlis Milta Rin Sondole. "Pengaruh Disiplin Kerja, Motivasi dan Pengawasan Terhadap Kinerja Karyawan Pada PT Pertamina (Persero) Unit Pemasaran VII Pertamina BBM Bitung”, Jurnal Emba: Jurnal Riset 
Ekonomi, Manajemen, Bisnis dan Akuntansi, Vol. 3 Nomor 3, 2015.

Muhammad Gary Akbar.Business Judgement Rule Sebagai Perlindungan Hukum Bagi Direksi Perseroan Dalam Melakukan Transaksi Bisnis, Jurnal Justisi Ilmu Hukum ISSN 2528-2638 Vol 1, N0 1, 2016.

Bayu Aji, Yogi. "Hotasi Berharap PK Dikabulkan Hakim untuk Kembalikan Uang Negara”, 2014.

SUMBER LAINNYA:

Putusan Mahkamah Konstitusi Nomor 62/PUU-XI/2013. 